\title{
Alberto Hijazo-Gascón* and Reyes Llopis-García* Applied cognitive linguistics and foreign language learning. Introduction to the special issue
}

https://doi.org/10.1515/iral-2018-2004

\begin{abstract}
This introduction provides an overview of the intersection between Applied Cognitive Linguistics and Second/Foreign Language Learning. First, the relevance of Cognitive Linguistics (CL) for Applied Linguistics in general is discussed. The second section explains the main principles of CL and how each relates to the acquisition of second languages: (i) language and human cognition, (ii) language as symbolic, (iii) language as motivated; and (iv) language as usagebased. Section three offers a review of previous literature on CL and L2s that are different from English, as it is one the main aims of this Special Issue to provide state-of-the-art research and scholarship to enhance the bigger picture of the field of Second Language Acquisition beyond English as the target language. Spanish as L2/FL in Applied Cognitive Linguistics is the focus of the next section, which leads to a brief overview of the papers included in the Issue, featuring Spanish as the L2 with L1s such as English, French, German and Italian. Polysemy, Motion Events Typology, Cognitive Grammar and Construction Grammar are the Cognitive Linguistics areas addressed in the contributions here presented.
\end{abstract}

Keywords: Cognitive Linguistics, Second Language Acquisition, Spanish, Polysemy, Motion Events, Cognitive Grammar, Construction Grammar

\section{Why is cognitive linguistics relevant to applied linguistics?}

Cognitive Linguistics (henceforth CL) is a theoretical approach that studies language as it relates to cognition, taking into consideration cultural, anthropological and psychological dimensions. CL starts in the United States as an

\footnotetext{
*Corresponding authors: Alberto Hijazo-Gascón, School of Politics, Philosophy, Language and Communication Studies, University of East Anglia, NR4 7TJ Norwich, UK, E-mail: A.Hijazo-Gascon@uea.ac.uk

Reyes Llopis-García, Department of Latin American and Iberian Cultures, Columbia University, 612 W116th Street, New York, NY 10027, USA, E-mail: rl2506@columbia.edu
} 
alternative model to Chomsky's Generative Linguistics, mainly due to the difficulties of studying semantics on the precepts of Universal Grammar. The fact that generativism focused mostly on syntax left aside other areas related to language such as cultural, historical, social and psychological aspects, crucial for other researchers who were primarily interested in the intersection between meaning and language. The impossibility of working on these areas, with semantics leading the charge, drove linguists such as Langacker, Lakoff or Talmy to find new grounds of research. Some of the literature milestones in this new path that would turn into a new framework of Linguistics are the publication of Metaphors we live by (Lakoff and Johnson 1980), Foundations of Cognitive Grammar (Langacker 1987) and Women, fire and dangerous things (Lakoff 1987). In Europe, the emergence of CL follows a different path, which undergoes a smoother progression rather than a radical change of paradigm, because authors like Dirven or Geeraerts were working from a functionalist perspective, which already was compatible with the principles of CL (see Nuyts 2007; also Butler and Gonzálvez-García 2014 for similarities and differences between CL and functionalism).

CL is technically neither one single framework, nor a homogeneous approach. Rather, it spans a number of theoretical models that share two main foundational principles, namely (i) to consider that language is an integral part of cognition, not in isolation but in relation to other cognitive abilities such as memory, attention and categorization; and (ii) to explain language from a semantic-pragmatic perspective, because it is perceived as usage-based rather than as a standalone human ability. According to Ibarretxe-Antuñano and Valenzuela (2012a), these CL theories include Frame semantics (Fillmore 1976), Conceptual Metaphor Theory (Lakoff and Johnson 1980), Conceptual Semantics (Talmy 1985), Cognitive Grammar (Langacker 1987), Construction Grammar (Goldberg 1995) and Conceptual Integration Blending (Fauconnier and Turner 1996). All these theories share the two principles mentioned above, but also look at language from different perspectives. They also share basic tenets that will be addressed in section $2 .^{1}$

Cognitive Linguistics has been a fruitful framework for different areas of Applied Linguistics, such as first language acquisition (Tomasello 2003; Lieven and Tomasello 2008), or translation and interpreting (Rojo and Ibarretxe-

1 There are a number of introductions to Cognitive Linguistics, such as Ungerer and Schmid (2006[1998]), Croft and Cruse (2004), Evans and Green (2006), Geeraerts and Cuyckens (2008), Littlemore and Taylor (2014), and Dąbrowska and Divjak (2015). Also in Spanish: Cuenca and Hilferty (1999) or Ibarretxe-Antuñano and Valenzuela (2012b). 
Antuñano 2013). However, Second Language Acquisition (henceforth SLA) has been the area that has received most of the attention, as evidenced by the amount of relevant literature: the volumes by Pütz et al. (2001a), Verspoor and Lowie (2003), Boers and Lindstromberg (2006, 2008), Robinson and Ellis (2008), de Knop and de Rycker (2008), Pütz and Siccola (2008), Cadierno and Eskildsen (2015), de Knop and Gilquin (2016), Tyler et al. (2018). Also, the special section in the Annual Review of Cognitive Linguistics (Ellis and Cadierno 2009), as well as the 2010 AILA Review (Littlemore and Juchem-Grundmann). CL has also been applied to L2 Pedagogy (Pütz et al. 2001b; Rudzka-Ostyn 2003; Lazar 2003; Achard and Niemeier 2004; Lindstromberg and Boers 2008; Holme 2009; Littlemore 2009; de Knop et al. 2010; Tyler 2012; Llopis-García et al. 2012; Castañeda Castro 2014; Masuda et al. 2015; Ibarretxe-Antuñano et al. 2019). Additionally, experimental research has shown how effective a CL-based methodology in the foreign language classroom can be (Lam 2009; Boers 2011; Colasacco this volume).

This Special Issue looks to contribute to the field and provide further evidence of the pedagogical benefits that CL can afford the instruction and study of second/foreign languages. In this introduction, the first focus will be on the theoretical tenets shared by all models under the field of CL. We will then direct our attention to the benefits and relevance of using a CL perspective in SLA. Consequently, the importance of researching from a cross-linguistic perspective will be highlighted in the next section. We will then present an overview of the productive influence of Cognitive Linguistics in the field of Spanish/L2, and finally, the papers included in this Special Issue will be introduced.

\section{Cognitive linguistics main tenets and their benefits for SLA}

Cognitive Linguistics oversees a number of different perspectives in the study of language that share certain tenets, all of them stemming from the understanding of language as a general part of cognition, and from the prominence given to semantic-pragmatic meaning over syntactic patterns. Following Geeraerts and Cuyckens (2008), Ellis and Cadierno (2009), and Ibarretxe-Antuñano and Valenzuela (2012a), these tenets are: (i) language is an integrated human ability, (ii) language is symbolic, (iii) language is motivated; and (iv) language is usagebased. For each of these ideas, we will go into detail below in order to show what they can bring to the study of SLA and L2 instruction. 


\subsection{Language is an integrated human ability}

Language needs to be understood in relation with other cognitive abilities such as perception, memory, categorization, attention, schematization or learning, and not as an isolated module in the mind. For example, categorization is a crucial concept in the study of language and cognition, as language phenomena can be understood in terms of categories around a prototype, with more central and more peripheral elements, rather than in terms of dichotomies. Rosch's (1973, 1975) pioneering experimental work on prototypes is a good example of how categories work and how, when we categorize, we compare items around a prototype. Her well-known example of the category of BIRD shows how sparrow, robin, or dove are more prototypical elements of this category, whilst penguin and ostrich are more marginal. This means that when we think of a bird, we are more likely to identify attributes in this category with a sparrow than with a penguin, and we will take the features of the prototypical element as an indicator when considering whether another entity is fit for this category or not (e. g. a peacock or a bat).

Understanding categorization can have a very practical application to L2 acquisition and instruction in relation to polysemy or grammatical constructions (see Taylor 2008 for a detailed account). For example, Gibbs (2005) uses this concept to explain English phrasal verbs, such as stand with different combinations (up, down, out, etc.). From a more prototypical sub-category: "achieving a vertical position", e. g. My leg hurts, I can't stand (up), to a less central subcategory: "retaining a vertical position", e. g. I can't stand this type of music, and finally to a more peripheral sub-category: "becoming prominent through vertical posture": She really stands out in the crowd, etc. Holme (2009) applies this analysis in the English/FL classroom by organizing these sub-categories and different meanings in a visual network, from more central to more peripheral meanings of phrasal verbs with stand. This is a more accessible way of acquiring the meanings of these phrasal verbs, especially if compared with endless lists of rules and exceptions that have been very frequently used in the teaching of English phrasal verbs. In Spanish as a Foreign Language, Llopis-García (2015) argues that prototypes provide embodied core meanings for prepositions that arise from spatial perceptions, and from which to create systematic semantic networks to account for polysemy. The categorization of prototypes in prepositions has the potential to present L2 students with an organized, comprehensible and motivated network of form-meaning connections, and to steer them away from divergent lists of random uses. Gómez Vicente (this volume) offers a prime example of categorization from a CL perspective for the highly polysemous verb quedar in Spanish. 
Another example of this integration of language with other cognitive abilities is in relation to perception and attention. We know from Gestalt Psychology that we pay attention to different aspects of a situation at different moments. For example, if you look from a seaside promenade at a crowded beach in the summer, you might focus your attention on the sea and the horizon to enjoy the landscape and consequently, you will pay less attention to the individuals sunbathing in the sand. However, if you are joining a group of friends who are already on the beach, your attention will shift from the sea to the crowd in the sand. Langacker names this phenomenon profiling and it entails paying attention to certain aspects of an event and to codify them saliently in the language. If a child breaks the vase on top of the living room table, she can encode the event as I broke the vase or The vase broke, depending on what aspects of the event she wishes to highlight. This has been widely applied to SLA, for example for the teaching of English prepositions (Tyler et al. 2011), as they can profile different elements such as surface (on), endpoint of direction (to) or containment (in). Profiling is also crucial when dealing with more schematic linguistic forms in the L2 classroom, such as the use of the subjunctive or the indicative mood in subordination in Spanish. In the first case, the subordinate verb in the subjunctive suspends its profile in favour of the verb in the main clause, whereas the subordinate indicative profiles its action as much as the one in the matrix clause (Llopis-García 2019).

\subsection{Language is symbolic}

Language is considered symbolic as it is based on the association of a phonetic form and a given meaning. This idea of symbolic meaning has been addressed from different perspectives. Langacker (1987) defines construals as the form-meaning pairings mediated by syntactic links and they are a crucial concept in his Cognitive Grammar. In the case of Construction Grammar, Goldberg $(1995,2003)$ considers that all grammatical phenomena can be understood as learned pairings of form, which applies to all range of linguistic items, from morphemes to idioms. There are some studies in SLA that have addressed different types of constructions in L2 English, such as the transitive construction (Mary cut the apple), the ditransitive construction (Mary cut John an apple), the resultative construction (Mary cut the apple open), and the caused-motion construction (Mary cut the apple into the basket). These studies showed that learners favor constructions over verbs when classifying sentences, and have focused on L2 English by learners whose L1s are Chinese (Liang 2002), German (Gries and Wulff 2005) and 
Spanish (Valenzuela and Rojo 2008), finding similar results in the way these speakers focus on the constructions. These results have highly relevant applications for the teaching of constructions or, rather, of their verbs, as it seems that a more efficient (and natural) way of acquiring them is by understanding how the construction works (see Ibarrexte-Antuñano and CheikhKhamis and also Gonzálvez-García, this volume). For example, Achard and Niemeier (2004) argue that the symbolic nature of grammatical constructions, including their semantics, is compatible with the goals and practices of communicative models of language teaching. A CL-based teaching approach, which emphasizes the relation between form-meaning connections and the communicative function of language, has been claimed to benefit from a pedagogical interaction with a focus-on-form instruction (Long 1991), as put forward by Ellis and Cadierno (2009) and shown in Cadierno (2008), LlopisGarcía (2011a) or Colasacco, this volume.

\subsection{Language is motivated}

Cognitive Linguistics considers that the associations of form and meaning that make language symbolic are not arbitrary, but motivated. In other words, language is embodied, i. e. shaped through our bodily, motor, physical, social, and cultural experiences (Johnson 1987). When we hear things like He was steaming or She was feeling low, we see emotions being described with conceptual metaphors such as ANGER IS LIQUID BOILING IN A CONTAINER or SADNESS IS DOWN. In this sense, conceptual metaphors clearly show how language is grounded in our physical experiences. Understanding language as motivated and not arbitrary has clear benefits in SLA and L2 instruction (see Lantolf and Bobrova 2014 for a detailed argument in favor of this view, HijazoGascón 2011 on the benefits of teaching conceptual metaphor for the development of communicative and learning strategies). Piquer-Píriz (2008) shows how young Spanish learners of English are able to find figurative meanings such as the head of the stairs in the L2 and grasp their figurative meaning. From a CL perspective, there is no difference between literal, figurative, linguistic and encyclopaedic meaning, which can lead to very positive results in L2 instruction at all levels of proficiency, from the most elementary into the most advanced. As studied by Boers and Lindstromberg (2006, 2008), adopting this approach can benefit the acquisition of the L2 greatly, particularly in relation to vocabulary (see Pérez-Serrano 2015 for additional empirical support of this claim). 


\subsection{Language is usage-based}

The actual use of language in communicative contexts is emphasized. Language learning occurs in relation to exposure to frequent patterns, and therefore the most recurrent chunks of language will be acquired earlier and faster. According to Tomasello (2003), the constructions of a language are learned through our linguistic experience when we communicate with others. In this sense, the frequency of the input is crucial for language acquisition. The fact that language is usage-based has an additional dimension: no theoretical assumption can be made unless it is supported with evidence of actual use in the language. In terms of methodology, research papers grounded in CL will necessarily need actual data to confirm or reject any hypothesis. This tenet presents a clear advantage for SLA in comparison to other theoretical frameworks, since theoretical introspection alone is not welcome. In this sense, Corpus Linguistics has become a good ally in providing evidence for CL theories in SLA. An example is Ellis and Ferreira-Junior's (2009) study on L2 English using two different learners' corpora. Their study focused on verbs and constructions and found that L2 learners first acquire the most frequent, prototypical and generic examples, like put in the Verb Object Locative construction Paul puts the cup on the table and give in the Verb Object Object construction Mary gives Paul a book. They show how the acquisition is affected by both frequency and frequency of distribution, as well as and their prototypicality. In light of studies like this and Ibarretxe-Antuñano and CheikhKhamis (this volume), it is suggested that teaching the semantic relation between the verb and its construction might facilitate learner extension of the construction to use with other verbs that are also appropriate.

Overall these tenets contribute to look at SLA phenomena from a different perspective that translates into and enriches different pedagogical practices for L2 instruction. Examples of these practices include the substitution of endless lists of rules and exceptions for grammatical categories with prototypes and semantic networks, or the training of students' metaphorical competence in vocabulary learning. At the same time, as Ellis and Cadierno (2009: 112) claim, SLA adds complexity to the understanding of Cognitive Linguistics, because in the process of "reconstructing a language" the L2 constructions are in competition with those of the learners' L1, and these may represent alternative ways of constructing the same reality, with the consequent risk for the occurrence of cross-linguistic influence. Given this point, the dialogue between CL and Applied Linguistics yields a fruitful exchange in both directions, and it is definitely worth exploring, with yet more exciting findings to come. 
On another note, there is a caveat in the current state of the art for this exchange that we aim to address with this Special Issue. English as L2 has received most of the attention of scholars working on this field and, beyond the important contributions that have thusly been achieved, we posit that more attention to other L2s is needed in order to obtain a better understanding of SLA as a process. Exploring other L2s is crucial, not only for the scholars who work on these languages and their L2 instruction, but also to address and include the wider SLA community. We believe that this is the most coherent way to achieve the bigger picture of both SLA and CL, and we tackle the point in the next section.

\section{Exploring SLA from the angle of other languages}

It is clear that the study of European languages, particularly English, is prominent in any field of linguistics, both applied and theoretical. The fact that English is the lingua franca used in science and the most widely taught second language gives it an advanced position as a point of comparison with any L1. As Piquer-Píriz and Alejo (2018) state, one of the contentions to overcome in research from a Cognitive Linguistics perspective is the fact that it is mainly focused on the study of the English language. However, we should not forget that studies in other target languages need to be supported, understood, and read by the wider SLA community. In this sense, Tyler and Huang (2018: 29) argue for the inclusion of different L2s and L1s, as it can deepen our understanding of cross-linguistic issues such as the nature of L1 transfer, and also demonstrate the applicability of the CL paradigm to learners of different L1 backgrounds.

In the case of Cognitive Linguistics applied to SLA, there have been a number of contributions that have expanded our views on how a second language is acquired, thanks to the attention given to different target languages. Some of the pioneering works are included in Achard and Niemeier's (2004b) volume, including Achard's (2004) work on Cognitive Grammar applied to French as an L2 (see also Achard 2018 for a recent application of Cognitive Grammar to L2 French impersonal constructions). Similarly, crucial concepts for the applications of conceptual metaphor theory have been created by authors working in different L2s. A clear example is that of Danesi (1988, 2008), who puts forward the concept of metaphorical competence as the knowledge of how the L2 encodes and represents abstract meanings through metaphor in L2 Italian by English-speakers. For applied studies on the development of the students' metaphorical competence in 
L2 Spanish, see the works by Acquaroni (2008) with American learners, Lamarti (2011) with Chinese speakers, and Masid (2017) with Slovak learners.

One of the areas that has received productive attention has been the acquisition of Talmy's (1991) Motion events typology ${ }^{2}$ and Slobin's (1991) thinking-forspeaking hypothesis. The seminal works by Cadierno $(2004,2008)$ are a clear example of how exploring languages different to English can bring relevant contributions to the theory. ${ }^{3}$ In her studies, Spanish, a verb-framed language, is chosen as the target language of Danish learners. Danish, a Germanic language with less influence from Romance languages, is a more prototypical satelliteframed language than English. She found that her participants tended to transfer L1 patterns and create "satellizations" in Spanish as an L2, such as *fue arriba de la roca "he went up the rock". This finding challenged previous assumptions that reconstructing the lexicalization patterns of motion events was relatively easy for satellite-framed language speakers when acquiring a verb-framed L2. This area of Motion events typology has been very fruitful in SLA (see Cadierno 2017 for an overview), including intra-typological variation (see among others Filipović and Vidaković 2010 for satellite-framed languages; Hijazo-Gascón 2018 for verb-framed languages), and also with respect to pedagogical approaches (de Knop and Dirven 2008 for L2 German). Even very specific aspects of motion, such as deictic motion verbs -come and go- have been explored from a very interesting array of language pairs: L2 Spanish-L1 Polish (Lewandowski 2014), -L1 French/German/Italian (Hijazo-Gascón 2017), -L1 German/Italian (Colasacco this volume); L2 JapaneseL1 Chinese/English (Yoshinari 2015), and L2 Greek-L1 Spanish/Catalan (Andria and Hijazo-Gascón 2018). The contribution in this volume by Muñoz and Cadierno adds to the field of Motion events typology, with a particular focus on bidirectional transfer in the cases of boundary-crossing.

For the case of placement events such as She put the cup on the table, the use of other languages has been particularly relevant. Gullberg (2009) studies several languages (Dutch, English, French and German) that differ in the encoding of these events. In Dutch, for example, as in other Germanic languages, it is key to know the position of the Figure, as the choice of verb will depend on whether its object is placed vertically (zetten "set") or horizontally (leggen "lay"). Gullberg (2009) found that these thinking-for-speaking patterns can be pervasive and even though her participants did not show cross-linguistic influence from Dutch when

2 Due to space restrictions we cannot explain Talmy's (1991, 2000) Motion events typology and Slobin's $(1991,1996)$ Thinking for Speaking hypothesis in detail, but a brief explanation can be found in Muñoz and Cadierno in this volume.

3 Other areas of Cognitive Linguistics have been also applied to other L2s, but we take Talmy's conceptual semantics as an example. 
describing put scenes in their L2 French verbs, their gestures still revealed that some of them were paying attention to the Figure being moved, while others showed a shift towards the target language semantics. In another study with Danish and Spanish as L1s and L2s, Cadierno et al. (2016) found that crosslinguistic differences occurred in both directions (see Hijazo-Gascón et al. 2016 for its pedagogical application). These findings shed light on some major difficulties that learners face when dealing with an L2 that presents strong cross-linguistic differences, and they would not have been uncovered in studies taking English as a sole point of comparison.

Finally, Construction Grammar has also been applied to SLA in different languages, as showcased in some of the studies collected in de Knop and Gilquin (2016). For example, de Knop and Mollica (2016) explore the ditransitive construction, similarly to the studies mentioned above, but in L2 German by Italian learners. In certain cases, L1 constructions seem to interfere in the L2 acquisition process, as claimed by Della Putta (2016), who proposes some activities to "unlearn" these L1 constructions for L2 Italian by L1 Spanish speakers. Other studies have developed a constructicon, taking into account both Construction Grammar and Frame Semantics in Swedish (Lonenheim et al. 2016) and German (Boas et al. 2016). The contributions in this Special Issue by Ibarretxe-Antuñano and Cheikh-Khamis and by Gonzálvez-García contribute to expand our knowledge on how constructions can be applied to different target languages.

\section{Cognitive linguistics and Spanish as an L2}

Spanish is becoming one of the most demanded languages in the world and consequently, research on its acquisition, learning and pedagogy is growing exponentially. This is evidenced by the increasing amount of publications on and about this language, such as handbooks (Lafford and Salaberry 2003; Geeslin 2013, 2018; Muñoz-Basols et al. 2018) and journals devoted to the acquisition and teaching of Spanish as a foreign or second language. Spanish has also been studied from a Cognitive Linguistics perspective (see Cadierno and HijazoGascón 2013 for an overview), and the forthcoming volume edited by IbarretxeAntuñano et al. (2019) presents both a theoretical approach and a number of descriptive and empirical applications of CL to Spanish from different areas: from Polysemy to Typology or Cognitive Grammar, to Translation and Discourse.

Cognitive Grammar is arguably the area that has received more attention, mainly on the language learning and pedagogical front, with a breadth of research and pedagogical approaches to Langacker's views in L2 Spanish aimed 
at scholars and language instructors alike. ${ }^{4}$ In the literature, Castañeda Castro (2012) and Castañeda Castro and Alhmoud (2014) offer a comprehensive overview of "Langackerian" terminology in the context of grammatical descriptions for advanced levels of Spanish. Categorization, profiling, perspective or schematicity are explained and exemplified within the language classroom and target the grammatical explanations of instructors. Llopis-García's research concentrates on mood selection $(2010,2019)$, the teaching of prepositions from a CL perspective (2015), or the advantages of teaching CL-based Spanish grammar (2011a, 2011b, 2016). Alonso-Aparicio and Llopis-García (2019) research tense and aspect for the preterit/imperfect distinction, and Ruiz Campillo (2014) details the inner workings of the Spanish verbal system from a core spatial representation.

We are also aware and know of a plethora of didactic proposals being researched and created in graduate studies within both master and $\mathrm{PhD}$ programs, but few (if any) options reach academic exposure beyond their graduate program or see their teaching materials published. ${ }^{5}$ This issue brings us to address one of the main obstacles to overcome in relation to the application of Cognitive Linguistics to SLA and L2 instruction: the lack of materials created from this perspective, as several of the contributions in this Special Issue also highlight. According to Tyler (2012) for CL and to Larsen-Freeman (2015) for SLA in general, the main findings of this line of research have not reached textbooks and classroom practice.

Although we agree that there is still much work to be done to "translate" the findings of Applied Cognitive Linguistics into textbooks and other teaching resources, we would like to emphasize that there are some relevant textbooks for teaching Spanish as an L2: El ventilador (Chamorro et al. 2006), Campus Sur (Rosales et al. 2017), and the Gramática Básica del Estudiante de Español [Basic Grammar for the student of Spanish] (Alonso Raya et al. 2006). These works are very popular among instructors of Spanish as an L2 and are also amply used in higher education contexts. They show a strong influence from Cognitive Grammar (Langacker 1987) and stem from a fruitful line of research on how Cognitive Grammar can be applied to the acquisition, learning and teaching of Spanish as a foreign language (Castañeda Castro 2004, 2006, 2012, Castañeda Castro and Alonso Raya 2009). Other materials also inspired by some aspects of

4 See the previous sections for studies on L2 Spanish in relation to other areas of CL such as Conceptual Metaphor, Construction Grammar and Cognitive Semantics.

5 Many can be found in the e-library for MA and PhD dissertations at the redELE website, funded by the Spanish Ministry of Education (http://www.educacionyfp.gob.es/educacion/ $\mathrm{mc} /$ redele/portada.html) 
CL are Fernández and Falk (2014) for grammar and Pérez Serrano (2017) for vocabulary.

Finally, another example of the good shape of Applied Cognitive Linguistics in a Spanish context was the first theme session on Applications of Cognitive Linguistics to Teaching Spanish as a Foreign Language, held at the Spanish Cognitive Linguistics Conference (AELCO) in 2016, which served as the origin of the present Special Issue. This was preceded by a general interest in CL and Applied Linguistics at AELCO 2014, which featured the topic as their main theme. The 2017 International Cognitive Linguistics Conference, celebrated in Estonia, included a session on SLA and Pedagogy with contributions from Spanish, and the 2019 Conference, slated to take place in Japan, offers Applied Linguistics and Pedagogy in the choice of topics for proposal submission. We hope that this line of work in Cognitive Linguistics and SLA research and pedagogy (and Spanish in particular) keeps shedding light on how we acquire second languages, and that the contribution that Spanish can offer is relevant to all researchers in SLA. This Special Issue highlights this interest and is hopefully a step forward in the right direction. Its contributions are described in the following section.

\section{Overview of the special issue}

Applied cognitive linguistics to L2 acquisition and learning: research and convergence brings new contributions to SLA and language learning from a Cognitive Linguistics perspective. In particular, the studies presented in this volume are grounded in different areas, such as Polysemy (Gómez-Vicente), Motion events typology (Muñoz and Cadierno), Cognitive Grammar (Colasacco), and Construction Grammar (Ibarretxe-Antuñano and Cheikh-Khamis; GonzálvezGarcía). All these papers signal a step forward in how these theoretical frameworks can contribute to the theoretical perspective of both L2 acquisition and learning, as well as how it may impact L2 instruction.

The first paper is by Gómez-Vicente, who tackles the highly polysemous verb quedar "to remain" in Spanish from a usage-based perspective and in search of a semantic categorization of its meanings. By analyzing native speaker production (both from adults and children) and comparing it to that of French learners of Spanish, she is able to elicit conclusions that may impact the teaching of polysemous verbs in an instruction setting. We then move on to the area of linguistic typology with Muñoz and Cadierno's paper on bidirectional transfer in the 
expression of Path between English/L1 and Spanish/L2. In their research, the authors compare the production of monolingual and bilingual native speakers, as well as that of learners of Spanish when retelling motion events with boundary and non-boundary crossings. Their findings shed light on the role of bidirectional transfer in L2 learners. Continuing with motion but moving away from Typology, Cognitive Grammar (CG) is represented by Colasacco's empirical study on deictic motion verbs and their instruction to L1 Italian and German students of Spanish. A CG-based approach to grammar instruction is combined with the focus on form methodology of Processing Instruction, yielding very positive results in favor of this pedagogical blend.

Finally, the two remaining papers deal with the field of Constructions. Ibarretxe-Antuñano and Cheikh-Khamis address pseudo-copulative change-ofstate verbs and the advantages of a Construction Grammar approach in order to better describe and understand their semantic categorization. Through a corpusbased constructional study of these verbs, the authors achieve a coherent and integrated account that may add a more effective value in the classroom setting. Such is also the main aim of our final paper, where Gonzálvez-García explores the family of subjective-transitive constructions with decir "say" in Spanish, in order to represent a unified categorization of the construction in its varying levels of specificity that may serve as an operational guide for students of Spanish/L2, and thus improve their access and comprehension of the target structure.

It is our hope that these papers will provide useful insight on the learning and acquisition of Spanish as a foreign language from the lens of Applied Cognitive Linguistics in its relationship with Second Language Acquisition. The works included in this Special Issue open new avenues and possibilities of research to deepen our understanding of how L2s are acquired, and of how L2 instruction can facilitate this process.

Acknowledgements: We would like to thank the authors in this Special Issue for accepting our proposal to participate in the theme session on Cognitive Linguistics and Spanish as a Second Language at the Spanish Cognitive Linguistics Conference (AELCO) in Alcalá de Henares in 2016, and for accepting our invitation to publish their contributions in this Special Issue. We would also like to thank Iraide Ibarretxe-Antuñano for "pushing" us to collaborate on this project and to gather experts in CL and Spanish as a Second Language for this purpose. This research has been supported by the Spanish Ministry of Economy and Competitiveness (CONESSO FFI201782460-P). 


\section{References}

Achard, Michel. 2004. Grammatical instruction in the natural approach: A cognitive grammar view. In Michel Achard \& Susanne Niemeier (eds.), Cognitive linguistics, second language acquisition and foreign language teaching, 165-194. Berlin: Mouton de Gruyter.

Achard, Michel. 2018. Teaching usage and concepts: Towards a cognitive pedagogical grammar. In Andrea Tyler, Lihong Huang \& Hana Jan (eds.), What is applied cognitive linguistics? Answers from current SLA research, 37-62. Berlin: Mouton de Gruyter.

Achard, Michel \& Susanne Niemeier. 2004a. Introduction: Cognitive linguistics, language acquisition, and pedagogy. In Michel Achard \& Susanne Niemeier (eds.), Cognitive linguistics, second language acquisition and foreign language teaching, 1-12. Berlin: Mouton de Gruyter.

Achard, Michel \& Susanne Niemeier (eds.). 2004b. Cognitive linguistics, second language acquisition and foreign language teaching. Berlin: Mouton de Gruyter.

Acquaroni Muñoz, Rosana. 2008. La incorporación de la competencia metafórica a la enseñanza-aprendizaje del español como segunda lengua a través de un taller de escritura creativa: un estudio experimental. Madrid: Universidad Complutense dissertation.

Alonso Raya, Rosario, Alejandro Castañeda Castro, Pablo Martínez Gila, Lourdes Miquel López, Jenaro Ortega Olivares \& José Plácido Ruiz Campillo. 2006. Gramática básica del estudiante de español. Barcelona: Difusión.

Alonso-Aparicio, Irene \& Reyes Llopis-García. 2019. La didáctica de la oposición imperfecto/ pretérito perfecto simple desde una perspectiva cognitiva. In Iraide Ibarretxe-Antuñano, Teresa Cadierno \& Alejandro Castañeda Castro (eds.), Lingüística cognitiva y español LE/L2. New York: Routledge.

Andria, María \& Alberto Hijazo-Gascón. 2018. Deictic motion verbs in Greek as a foreign language by Spanish and Catalan L1 learners: A preliminary approach. Glossologia 26. 121-135.

Boas, Hans C., Ryan Lux \& Alexander Ziem. 2016. Frames and constructions in an online learner's dictionary. In Sabine de Knop \& Gaëtanelle Gilquin (eds.), Applied construction grammar, 303-326. Berlin: Mouton de Gruyter.

Boers, Frank. 2011. Cognitive semantic ways of teaching figurative phrases: An assessment. Review of Cognitive Linguistics 9(1). 227-261.

Boers, Frank \& Seth Lindstromberg. 2006. Cognitive linguistic applications in second and foreign language instruction: Rationale, proposals, and evaluation. In Gitte Kristiansen, Michel Achard, René Dirven \& Francisco Ruiz de Mendoza Ibáñez (eds.), Cognitive linguistics: Current applications and future perspectives, 305-355. Berlin: Mouton de Gruyter.

Boers, Frank \& Seth Lindstromberg (eds.). 2008. Cognitive linguistic approaches to teaching vocabulary and phraseology. Berlin: Mouton de Gruyter.

Butler, Christopher S. \& Francisco Gonzálvez-García. 2014. Exploring functional-cognitive space. Amsterdam: John Benjamins.

Cadierno, Teresa. 2004. Expressing motion events in a second language: A cognitive typological perspective. In Michel Achard \& Susanne Niemeier (eds.), Cognitive linguistics, second language acquisition and foreign language teaching, 13-49. Berlin: Mouton de Gruyter.

Cadierno, Teresa. 2008. Motion events in Danish and Spanish: A focus-on-form pedagogical approach. In Sabine de Knop \& Teun de Rycker (eds.), Cognitive approaches to pedagogical grammar, 259-294. Berlin: Mouton de Gruyter. 
Cadierno, Teresa. 2017. Thinking for speaking about motion in a second language: Looking back and forward. In Iraide Ibarretxe-Antuñano (ed.), Motion and space across languages: Theory and applications, 279-300. Amsterdam: John Benjamins.

Cadierno, Teresa \& Alberto Hijazo-Gascón. 2013. Cognitive linguistics and the acquisition of L2 Spanish. In Kimberly L. Geeslin (ed.), The handbook of Spanish second language acquisition, 96-110. Malden, MA: Wiley-Blackwell.

Cadierno, Teresa \& Søren W. Eskildsen (eds.). 2015. Usage-based perspectives on second language learning. Berlin: Mouton de Gruyter.

Cadierno, Teresa, Iraide Ibarretxe-Antuñano \& Alberto Hijazo-Gascón. 2016. Semantic categorization of placement verbs in L1 and L2 Danish and Spanish. Language Learning 66(1). 191-223.

Castañeda Castro, Alejandro. 2004. Potencial pedagógico de la gramática cognitiva. Pautas para la elaboración de una gramática pedagógica del español/LE. redELE 0. 1-23.

Castañeda Castro, Alejandro. 2006. Aspecto, perspectiva y tiempo de procesamiento en la oposición Imperfecto/Indefinido del español. Ventajas explicativas y aplicaciones pedagógicas. RAEL: Revista Electrónica De Lingüística Aplicada 5. 107-140.

Castañeda Castro, Alejandro. 2012. Perspective and meaning in pedagogical descriptions of Spanish as a foreign language. In Guadalupe Ruiz Fajardo (ed.), Methodological developments in teaching Spanish as a second and foreign language, 221-272. Newcastle: Cambridge Scholars.

Castañeda Castro, Alejandro (ed.), 2014. Enseñanza de gramática avanzada de ELE. Criterios y recursos. Madrid: SGEL.

Castañeda Castro, Alejandro \& Zeina Alhmoud. 2014. Gramática cognitiva en descripciones gramaticales para niveles avanzados de ELE. In Alejandro Castañeda Castro (ed.), Enseñanza de gramática avanzada de ELE. Criterios y recursos, 39-85. Madrid: SGEL.

Castañeda Castro, Alejandro \& Rosario Alonso Raya. 2009. La percepción de la gramática. Aportaciones de la lingüística cognitiva y la pragmática a la enseñanza del español/LE. Marcoele 8. 1-33.

Chamorro, María Dolores, Gracia Lozano, Aurelio Ríos Rojas, Guadalupe Ruiz Fajardo \& José Plácido Ruiz Campillo. 2006. El Ventilador. Curso de español de nivel superior. Barcelona: Difusión.

Croft, William \& D.Alan Cruse. 2004. Cognitive linguistics. Cambridge: Cambridge University Press.

Cuenca, María Josep \& Joseph Hilferthy. 1999. Introducción a la lingüística cognitiva. Barcelona: Ariel.

Dąbrowska, Ewa \& Dagmar Divjak (eds). 2015. Mouton handbook of cognitive linguistics. Berlin: Mouton de Gruyter.

Danesi, Marcel. 1988. The development of metaphorical competence: A neglected dimension in second language pedagogy. In Albert N. Mancini, Paolo Giordano \& Pier Raimondo Baldini (eds.), Selected Papers from the Proceedings of the Third Annual Conference of the American Association of Teachers of Italian, 1-10. River Forest, IL: Italiana.

Danesi, Marcel. 2008. Conceptual errors in second language learning. In Sabine de Knop \& Teun de Rycker (eds.), Cognitive approaches to pedagogical grammar, 231-256. Berlin: Mouton de Gruyter.

De Knop, Sabine, Frank Boers \& Teun de Rycker (eds.). 2010. Fostering language teaching efficiency through cognitive linguistics. Berlin: Mouton de Gruyter. 
De Knop, Sabine \& Teun de Rycker (eds.). 2008. Cognitive approaches to pedagogical grammar. Berlin: Mouton de Gruyter.

De Knop, Sabine \& René Dirven. 2008. Motion and location events in German, French and English: A typological, contrastive and pedagogical approach. In Sabine de Knop \& Teun de Rycker (eds.), Cognitive approaches to pedagogical grammar, 295-324. Berlin: Mouton de Gruyter.

De Knop, Sabine \& Gaëtanelle Gilquin (eds.). 2016. Applied construction grammar. Berlin: Mouton de Gruyter.

De Knop, Sabine \& Fabio Mollica. 2016. A corpus-based analysis of German ditransitive phraseologisms for language pedagogy. In Sabine de Knop \& Gaëtanelle Gilquin (eds.), Applied construction grammar, 53-88. Berlin: Mouton de Gruyter.

Della Putta, Paolo. 2016. Do we also need to unlearn constructions? The case of constructional negative transfer from Spanish to Italian and its pedagogical implications. In Sabine de Knop \& Gaëtanelle Gilquin (eds.), Applied construction grammar, 237-268. Berlin: Mouton de Gruyter.

Ellis, Nick C. \& Teresa Cadierno. 2009. Constructing a second language: Introduction to the special section. Annual Review of Cognitive Linguistics 7. 111-139.

Ellis, Nick C. \& Fernando Ferreira-Junior. 2009. Constructions and their acquisition: Islands and the distinctiveness of their occupancy. Annual Review of Cognitive Linguistics 7. 197-220.

Evans, Vyvyan \& Melanie Green. 2006. Cognitive Linguistics. An Introduction. Edinburgh: Edinburgh University Press.

Fauconnier, Gilles \& Mark Turner. 1996. Blending as a central process of grammar. In Adele E. Goldberg (ed.), Conceptual structure and discourse, 113-130. Stanford: CSLI Publications.

Fernández, Susana S. \& Johan Falk (eds.). 2014. Temas de gramática española para estudiantes universitarios. Frankfurt: Peter Lang.

Filipović, Luna \& Vidaković. Ivana. 2010. Typology in the L2 classroom. Second language acquisition from a typological perspective. In Martin Pütz \& Laura Sicola (eds.), Inside the learner's mind: Cognitive processing in second language acquisition, 269-291.

Amsterdam: John Benjamins.

Fillmore, Charles. 1976. Frame semantics and the nature of language. Annals of the New York Academy of Sciences: Conference on the Origin and Development of Language and Speech 280. 20-32.

Geeraerts, Dirk \& Hubert Cuyckens (eds.). 2008. The Oxford Handbook of Cognitive Linguistics. Oxford: Oxford University Press.

Geeslin, Kimberly L (ed.). 2013. The handbook of Spanish second language acquisition. Malden, MA: Wiley-Blackwell.

Geeslin, Kimberly L (ed.). 2018. The Cambridge handbook of Spanish linguistics. Cambridge: Cambridge University Press.

Gibbs, Raymond W. 2005. Embodiment and cognitive science. Cambridge: Cambridge University Press.

Goldberg, Adele E. 1995. Constructions. A construction grammar approach to argument structure. Chicago: University of Chicago Press.

Goldberg, Adele E. 2003. Constructions: A new theoretical approach to language. Trends in Cognitive Science 7(5). 219-224.

Gries, Stefan Th. \& Stefanie Wulff. 2005. Do foreign language learners also have constructions?. Annual Review of Cognitive Linguistics 3(1). 182-200. 
Gullberg, Marianne. 2009. Gestures and the development of semantic representations in first and second acquisition. AILE Lia 1. 117-139.

Hijazo-Gascón, Alberto. 2011. Las metáforas conceptuales como estrategias comunicativas y de aprendizaje: Una aplicación didáctica de la lingüística cognitiva. Hispania 94(1). 142-154.

Hijazo-Gascón, Alberto. 2017. Motion event contrasts in Romance languages: Deixis in Spanish as a second language. In Iraide Ibarretxe-Antuñano (ed.), Motion and space across languages, 301-328. Amsterdam: John Benjamins.

Hijazo-Gascón, Alberto. 2018. Acquisition of Motion Events in L2 Spanish by German, French and Italian speakers. The Language Learning Journal 46(3). 241-262.

Hijazo-Gascón, Alberto, Teresa Cadierno \& Iraide Ibarretxe-Antuñano. 2016. Learning the placement caused motion construction in L2 Spanish. In Sabine de Knop \& Gaëtanelle Gilquin (eds.), Applied construction grammar, 185-210. Berlin: Mouton de Gruyter.

Holme, Randal. 2009. Cognitive Linguistics and Language Teaching. Basingstoke, UK: Palgrave Macmillan.

Ibarretxe-Antuñano, Iraide, Teresa Cadierno \& Alejandro Castañeda Castro (eds.). 2019. Lingüística cognitiva y español LE/L2. New York: Routledge.

Ibarretxe-Antuñano, Iraide \& Javier Valenzuela. 2012a. La lingüística cognitiva: Origen, principios y tendencias. In Iraide Ibarretxe-Antuñano \& Javier Valenzuela (eds.), Lingüística cognitiva, 13-38. Barcelona: Anthropos.

Ibarretxe-Antuñano, Iraide \& Javier Valenzuela (eds.). 2012b. Lingüística cognitiva. Barcelona: Anthropos.

Johnson, Mark. 1987. The body in the mind. The bodily basis of meaning, reason and imagination. Chicago: University of Chicago Press.

Lafford, Barbara \& Rafael Salaberry (eds.). 2003. Spanish second language acquisition: State of the science. Washington D.C: Georgetown University Press.

Lakoff, George. 1987. Women, Fire, and Dangerous Things: What Categories Reveal about the Mind. Chicago: University of Chicago Press.

Lakoff, George \& Mark Johnson. 1980. Metaphors We Live by. Chicago: University of Chicago Press.

Lam, Yvonne. 2009. Applying Cognitive Linguistics to teaching the Spanish prepositions por and para. Language Awareness 18 (1). 2-18.

Lamarti, Rachid. 2011. La conceptualización metafórica en aprendientes sinófonos de E/LE. SinoELE Suplementos 5. 1-72.

Langacker, Ronald W. 1987. Foundations of Cognitive Grammar. Volume I. Theoretical Prerequisites. Stanford: Stanford University Press.

Lantolf, James P \& Larysa Bobrova. 2014. Metaphor instruction in the L2 Spanish classroom: Theoretical argument and pedagogical program. Journal of Spanish Language Teaching 1(1). 46-61.

Larsen-Freeman, Diane. 2015. Research into practice: Grammar learning and teaching. Language Teaching 48(2). 263-280.

Lazar, Gillian. 2003. Meanings and metaphors. Activities to practice figurative language. Cambridge: Cambridge University Press.

Lewandowski, Wojciech. 2014. Deictic verbs: Typology, thinking for speaking and SLA. SKY Journal of Linguistics 27. 43-65.

Liang, Junying. 2002. How do Chinese EFL learners construct sentence meaning: Verb-centered or construction-based? M.A. thesis. Guandong University of Foreign Studies. 
Lieven, Elena V. \& Michael Tomasello. 2008. Children's first language acquisition from a usagebased perspective. In Peter Robinson \& Nick C. Ellis (eds.), Handbook of cognitive linguistics and second language acquisition, 168-196. New York: Routledge.

Lindstromberg, Seth \& Frank Boers. 2008. Teaching chunks of language: From noticing to remembering. London: Helbling Languages.

Littlemore, Jeannette. 2009. Applying cognitive linguistics to second language learning and Teaching. Basingstoke, UK: Palgrave Macmillan.

Littlemore, Jeannette \& Constanze Juchem-Grundmann (eds.). 2010. Applied cognitive linguistics in second language learning and teaching. [Special Issue]. AILA Review 23.

Littlemore, Jeannette \& John Taylor (eds.). 2014. The Bloomsbury Companion to Cognitive Linguistics. London: Bloomsbury.

Llopis-García, Reyes. 2010. Why cognitive grammar works in the L2 classroom: A case study of mood selection in Spanish. In Jeannette Littlemore \& Constanze Jochem-Grundmann (eds.) 2010. Applied cognitive linguistics in second language learning and teaching. [Special Issue]. AlLA Review 23. 72-94.

Llopis-García, Reyes. 2011a. Gramática cognitiva para la enseñanza del español como lengua extranjera [Digital Edition]. Madrid: Ministerio de Educación, Cultura y Deportes.

Llopis-García, Reyes. 2011b. La gramática cognitiva: Nuevas avenidas para la enseñanza de lenguas extranjeras. Verba Hispanica 19 (1). 111-127.

Llopis-García, Reyes. 2015. Las preposiciones y la metáfora del espacio: Aportaciones y potencial de la lingüîstica cognitiva para su enseñanza. Journal of Spanish Language Teaching 2(1). 51-68.

Llopis-García, Reyes. 2016. Using cognitive principles in teaching Spanish L2 grammar. In M. del Carmen Méndez Santos (ed.). Nuevas perspectivas en la enseñanza del español como lengua extranjera. [Special Issue]. Hesperia XIX(2). 29-50.

Llopis-García, Reyes. 2019. Gramática cognitiva y selección modal en la enseñanza del español LE/L2. In Iraide Ibarretxe-Antuñano, Teresa Cadierno \& Alejandro Castañeda Castro (eds.), Lingüística cognitiva y español LE/L2. New York: Routledge.

Llopis-García, Reyes, Juan Manuel Real Espinosa \& José Plácido Ruiz Campillo. 2012. Qué gramática aprender, qué gramática enseñar. Madrid: Edinumen.

Loenheim, Lisa, Benjamin Lyngfelt, Joel Olofsson, Julia Prentice \& Sofia Tingsell. 2016.

Constructicography meets (second) language education: On Constructions in teaching aids and the usefulness of a Swedish constructicon. In Sabine de Knop \& Gaëtanelle Gilquin (eds.), Applied construction grammar, 327-356. Berlin: Mouton de Gruyter.

Long, Michael H. 1991. Focus on form: A design feature in language teaching methodology. In Kees de Bot, Ralph Ginsberg \& Claire Kramsch eds., Foreign language research in cross-cultural perspectives, 39-52. Amsterdam: John Benjamins.

Masid Blanco, Ocarina. 2017. La metáfora lingüística en español como lengua extranjera (ELE). Estudio pre-experimental en tres niveles de competencia. Porta Linguarum 27. 155-170.

Masuda, Kyoko, Carlee Arnett \& Angela Labarca (eds.). 2015. Cognitive linguistics and sociocultural theory: Applications for second and foreign language teaching. Berlin: Mouton de Gruyter.

Muñoz Basols, Javier, Elisa Gironzetti \& Manel Lacorte (eds.). 2018. The Routledge handbook of Spanish language teaching: Metodologías, contextos y recursos para la enseñanza del español L2. New York: Routledge. 
Nuyts, Jan. 2007. Cognitive linguistics and functional linguistics. In Dirk Geeraerts \& Hubert Cuyckens (eds.), The Oxford handbook of cognitive linguistics, 543-565. Oxford: Oxford University Press.

Pérez Serrano, Mercedes. 2015. Un enfoque léxico a prueba: efectos de la instrucción en el aprendizaje de las colocaciones léxicas. Salamanca: University of Salamanca dissertation.

Pérez Serrano, Mercedes. 2017. La enseñanza/aprendizaje del vocabulario en ELE desde los enfoques léxicos. Madrid: Arco Libros.

Piquer-Píriz, Ana María. 2008. Reasoning figuratively in early EFL: Some implications for the development of vocabulary. In Frank Boers \& Seth Lindstromberg (eds.), Cognitive linguistic approaches to teaching vocabulary and phraseology, 219-240. Berlin: Mouton de Gruyter.

Piquer-Píriz, Ana María \& Rafael Alejo-González. 2018. Applying cognitive linguistics: Identifying some current research foci (figurative language in use, constructions and typology). In Ana María Piquer-Píriz \& Rafael Alejo-González (eds.), Applying cognitive linguistics. Figurative language in use, constructions and typology, 1-19. Amsterdam: John Benjamins.

Pütz, Martin, Susanne Niemeier \& René Dirven (eds.). 2001a. Applied Cognitive Linguistics I: Theory and Language Acquisition. Berlin: Mouton de Gruyter.

Pütz, Martin, Susanne Niemeier \& René Dirven (eds). 2001b. Applied cognitive linguistics II: Language pedagogy. Berlin: Mouton de Gruyter.

Pütz, Martin \& Laura Sicola. 2008. Cognitive Processing in Second Language Acquisition. Amsterdam: John Benjamins.

Robinson, Peter \& Nick C. Ellis (eds.). 2008. Handbook of cognitive linguistics and second language acquisition. New York: Routledge.

Rojo, Ana \& Iraide Ibarretxe-Antuñano (eds.). 2013. Cognitive linguistics and translation: Advances in some theoretical models and applications. Berlin: Mouton de Gruyter.

Rosales, Francisco, Teresa Moreno, Ana Martínez Lara, Pilar Salamanca, Kris Buyse, Matilde Martínez, Núria Murillo \& Pablo Garrido. 2017. Campus Sur: Curso intensivo de español. Barcelona: Difusión.

Rosch, Eleanor. 1973. Natural categories. Cognitive Psychology 4. 328-350.

Rosch, Eleanor. 1975. Cognitive representations of semantic categories. Journal of Experimental Psychology: General 104. 192-233.

Rudzka-Ostyn, Brygida. 2003. Word power: Phrasal verbs and compounds. A cognitive approach. Berlin: Mouton de Gruyter.

Ruiz Campillo, José Plácido. 2014. La lógica del espacio. Un mapa operativo del sistema verbal en español. Journal of Spanish Language Teaching 1(1). 62-85.

Slobin, Dan I. 1991. Learning to think for speaking. Native language, cognition and rhetorical style. Pragmatics 1. 7-29.

Slobin, Dan I. 1996. From 'thought and language' to 'thinking for speaking'. In John J. Gumperz \& Stephen C. Levinson (eds.), Studies in the social and cultural foundations of language, 70-96. Cambridge: Cambridge University Press.

Talmy, Leonard. 1985. Lexicalization patterns: Semantic structure in lexical forms. In Timothy Shopen (ed.), Language typology and lexical descriptions: Vol. 3. Grammatical categories and the lexicon, 36-149. Cambridge: Cambridge University Press.

Talmy, Leonard. 1991. Path to realization: A typology of event conflation. Proceedings of the Seventeenth annual meeting of the Berkley Linguistic Society 17. 480-519. 
Talmy, Leonard. 2000. Toward a cognitive semantics. Cambridge, MA: The MIT Press.

Tomasello, Michael. 2003. Constructing a language: A usage-based theory of language. Cambridge, MA: Harvard University Press.

Tyler, Andrea. 2012. Cognitive linguistics and second language learning: Theoretical basis and experimental evidence. New York: Routledge.

Tyler, Andrea \& Lihong Huang. 2018. Introduction. In Andrea Tyler, Lihong Huang \& Hana Jan (eds.), What is applied cognitive linguistics? Answers from current SLA research, 1-34. Berlin: Mouton de Gruyter.

Tyler, Andrea, Lihong Huang \& Hana Jan (eds.). 2018. What is applied cognitive linguistics? Answers from current SLA research. Berlin: Mouton de Gruyter.

Tyler, Andrea, Charles Mueller \& Ho Vu. 2011. Applying cognitive linguistics to learning the semantics of English to, for and at: An experimental investigation. Vigo International Journal of Applied Linguistics 8. 181-205.

Ungerer, Friedrich \& Hans-Jörg Schmid. 2006[1998]. An introduction to cognitive linguistics. London: Longman.

Valenzuela, Javier \& Ana María Rojo. 2008. What can language learners tell us about constructions?. In Sabine de Knop \& Teun de Rycker (eds.), Cognitive approaches to pedagogical grammar, 197-229. Berlin: Mouton de Gruyter.

Verspoor, Marjolyn \& Wander Lowie. 2003. Making sense of polysemous words. Language Learning 53. 547-586.

Yoshinari, Yuko. 2015. Describing motion events in Japanese L2 acquisition: How to express deictic information. In Iraide Ibarretxe-Antuñano \& Alberto Hijazo-Gascón (eds.), New horizons in the study of motion: Bringing together applied and theoretical perspectives, 32-63. Newcastle: Cambridge Scholars. 